\title{
Classroom Management Talk in Teaching English at SMPN 2 Watampone
}

\author{
Mukhlis \\ Mukhlislee12@gmail.com \\ SMPN 2 Watampone, South Sulawesi, Indonesia
}

\begin{abstract}
This paper depicts the transactional expressions used by the teacher in teaching English, the students' understanding of those transactional expression used, and the transactional expressions which gave benefit to the students. There were twenty two students and one English teacher involved as the subjects. The subjects were the students of the seventh grade of A of SMPN 2 Watampone and an English teacher who taught English in that class. This research employed a descriptive qualitative method by using a discourse analysis. The triangulation data were applied in this research. The researcher used observation sheet that entailed video recording to collect the data about the transactional expressions used by the teacher. To get deeper data about the transactional expressions used by the teacher, the researcher also employed interview instrument entailing audio recording. An open ended questionnaire was also distributed to the students to know about their understanding of the transactional expressions used by the teacher and the transactional expressions which gave benefit to them. The findings of this research revealed the real transactional expressions (management talk) used by the teacher in teaching English, the percentage of the students' understanding of the transactional expressions used, and the beneficial transactional expressions for them.
\end{abstract}

Keywords: Classroom interaction, Management talk (transactional expressions), Students' understanding, the beneficial transactional expressions, English Teacher, Students

\section{INTRODUCTION}

The teaching of English as a foreign language in Indonesia is very important since most people use English as a tool for international communication. In relation to the objectives of teaching English above, Krashen in Wang (2014: 1-2) thinks that learners can acquire language unless sufficient comprehensible input is given. The input should be meaningcentered instead of form-centered. As for successful language acquisition input, the most important thing is providing language learners with as much comprehensible as possible. In second language study, teacher talk is the most rich, most reliable source of comprehensible input. Communication is more favorable for language acquisition than one-way communication. In two-way communication, when one party can't understand the other party, they will have chances to communicate with the other party to urge two 
parties to negotiate meaning and adjust interact with the aim of raising the intelligibility of language input.

Besides necessary comprehensible language input, learners should have the opportunity to output language in order to make the accuracy and fluency of their language reach the level of native speakers. The meaningful interactive activity learners participate as "being driven" so as to develop their language competence. So in the classroom, communication can provide learners with comprehensible language input up to the hilt. Both the teacher and the learner can adopt effective communicative strategy to make themselves understood by others. Negotiation of meaning is encouraged when problems emerge during communication and teachers should apply strategy to encourage learners to reorganize their language.

Specifically, Rasyid (2012:1) stated that one of very important factors to gain the objectives of English teaching is the use of English as an instructional talk as one of parts of teacher talk in the classroom interaction. English as an instructional talk will be a direct input to acquire. Therefore, the use of English as an instructional talk is a need in the classroom interaction designed by lecturer or teacher to create an effective classroom interaction for students to grasp input to be an intake as a model of English use accordingly.

However, when a teacher uses totally instructional talk in teaching English in the classroom interaction, not all students can catch or understand well the instructional talk given by the teacher. It is caused by the students' ability in using English is still diverse. This constraint makes a teacher should use classroom management talk (management talk) as the other part of teacher talk to manage the classroom activities. At least an English teacher uses management talk in activity - based, namely phases of activities at the beginning of the class, running the class and ending the lesson. To create an effective classroom interaction for students to grasp input to be an intake as a model of English use accordingly, a teacher at least should manage his talk when teaching English. He or she should manage his or her transactional expressions from the very beginning to the very end of the class session.

It is very important to manage transactional expression used by the teacher to manage the classroom activities effectively and efficiently such as entering the class, greeting students, arranging the students' seats, calling the rolls or checking the students' presence, dealing with lateness, telling the objectives, checking progress, taking turns, and ending the class. The teacher talk is considered to be a problematic area for teacher in teaching English. It should promote genuine and natural classroom communication. Good teacher talk should be judged by its effectiveness to facilitate learning and promote communicative interaction in the classroom.

The language used by the teacher or "teacher talk" in classroom interaction is very important. Xiao-Yan (2006) assumed that a teacher's language is not only the object of the course, but also the medium to achieve the teaching objective. Both organization of the classroom and teaching goals are achieved through the teacher talk. Moreover, language teachers can use their talk as a tool to maximize the student performance and interaction and also to promote positive attitudes toward the teacher. 
Since not all students can catch or understand well when the teachers use English in teaching English, it would be better a teacher uses management talk based on the phases of classroom activities(activity-based) as Rasyid (2012) did at his research grant to his students in English Education Program, Faculty of Language and Literature, State University of Makassar. Considering the notion stated above, I was interested in finding the English management talk which is activity-based, especially “ the transactional expressions applied by the English teacher of SMPN 2 Watampone to manage the classroom talks in teaching and learning English in beginning the lesson, running the class, and ending the lesson.

In this paper, I depict the transactional expressions used by the teacher in teaching English, the students' understanding of the transactional expressions used, and the benefit for the students. The main intention is to know what transactional expressions used by the teacher, the students' understanding and the benefit for them.

This study is meant to give valuable inputs to the English language teaching as a whole. It is expected to give contribution to the teachers of English in using verbal communication strategies in managing their class effectively and efficiently. It is also hoped to give contribution to create a good interpersonal interaction that can help the students to increase their achievement in language acquisition. It is expected to be the major source of comprehensible target input the learner is likely to receive. With the specific area that I address in this paper that is in Indonesia, focusing in one junior high school in Bone, South Sulawesi, Indonesia, that is the SMPN 2 Watampone, I attempt to explore the transactional expressions as management talk used by the teacher in helping the students to give a good input in language acquisition and how the students understand about them.

\section{CONCEPTS OF CLASSROOM MANAGEMENT AND MANAGEMENT TALK}

Classroom management is very crucial to create an effective and efficient teaching and learning process. Everything and everyone must be managed when entering and teaching in the class. Rasyid (2012:10) states that classroom management is an essential part in determining the success of learning process in the classroom. Rasyid then divides classroom management into three points, namely (1) planning which involves the organization procedures and learning sources, time organization, and representative space which is needed to maximize the efficiency and monitoring the students learning progress, and to anticipate the problems that would probably happen; (2) communication which informs the students about the objectives which will be gained and what we hope from them; and (3) control that involves lectures or teachers and students to create and keep the good situation in teaching and learning process in the class.

Furthermore, Rasyid (2012:20) states that a good classroom management will (1) present a comfortable environment, (2) build the students' responsibility, (3) increase the students' participation and motivation, and (4) empower the sense of mutual aids and mutual needs. From the statements above we know that classroom management is very crucial to create an effective and efficient teaching and learning process to ensure that classroom lessons run smoothly despite disruptive behavior. It is closely linked to issues of motivation, discipline and respect as skills teachers need to acquire. 
The management talk deals with the enforcement of classroom activities, such as entering the class, greeting students, arranging the students' seats, calling the rolls or checking the students' presence, dealing with lateness, starting something new, telling the objectives, checking the progress, stopping work, making announcement, and clearing the class. Management talk consists of transactional expressions that are used to manage the interaction in the class from the very beginning to the very end of the class session (Rasyid, 2012: 1).

Doff (1993) in Rasyid (2012:14) divides classroom management talks into fifteen language functions as follows: (1) Greeting, (2) Instruction, (3) Asking for information, (4) Talk/chatting to students, (5)Checking attendance, (6) Grouping/telling students where to sit, (7) Encouraging, (8) Giving turn, (9)Thanking, (10) Apologizing, (11) Advising, (12) Acknowledging, (13) Asking to do something, (14) Marker, and (15) Ending lesson/topic.

Then, Rasyid (2012:18-19) exposes some typical phases of classroom activities (activitybased) that can be managed as the management talk are: (a) Starting or beginning the lesson that can cover the activities as follows: (1) Entering the classroom, (2) Everyday greeting, (3) Meeting a new class, (4)Taking the Register, (5) Being late and dealing with the lateness, and (6) Getting down to start; (b) Running the class which covers the activities as follows: (1) Beginning with revision, (2) Starting something new, (3) Telling the objectives, (4) Making things clear/Checking students' understanding, (5) Sequencing activities, (6) Checking progress, and (7) Taking Turns; (c) Ending or closing the lesson which consists of some stages $\mathrm{f}$ language function as follows: (1) Checking the time, (2) Setting taking home assignment, (3) Stopping work, (4) Making announcement, (5) Ending the lesson, (6) Saying good bye, and (7) Clearing the class.

It can be concluded that Management talk is the utterances or transactional expressions that are used to manage the classroom interaction between teacher and pupils in the class from the very beginning to the very end of the class session.

\section{RESEARCH DESIGN AND DATA COLLECTION}

This is a descriptive study employing three kinds of research instruments that consists of observation entailing video recording and observation sheet, interview entailing audio recording and an open ended-questionnaire. This study was conducted at one of the Junior High School in Bone South Sulawesi, Eastern Indonesia, namely the SMPN 2 Watampone. The subjects were one English teacher and twenty two students of SMPN 2 Watampone at the Seventh Grade in academic year 2014/2015.

To find data on the transactional expressions used by the teacher I interviewed the teacher before entering the classroom to get a beginning data. Then, I observed her using observation sheet while recording her by using video for three times or three meetings. To find out the students understanding of the transactional expressions used and the benefit for the students, I distributed an open ended-questionnaire to the twenty two students in the forms of closed-ended questions whether they strongly understand, understand, less understand, don't understand, or strongly don't understand. I used descriptive statistics to analyze the data based on the rate percentage. 


\section{FINDINGS}

In this part, I elaborate the findings gained from the interview, observation and questionnaire in terms of the transactional expressions used by the teacher, the students' understanding of the transactional expressions used, and the benefit to the students.

\section{The Transactional Expressions used by the Teacher}

The first finding from this research is about the transactional expressions (management talk) used by the teacher to manage the classroom activities in teaching English. This can be seen in the following table:

Table 1

Transactional expressions used by the teacher in teaching English in the classroom from beginning the lesson, running the class, and ending the lesson

\begin{tabular}{|c|c|c|}
\hline No. & $\begin{array}{l}\text { The Data Based on the } \\
\text { Observation }(*)\end{array}$ & The Data Based on the Interview (**) \\
\hline \multirow{2}{*}{1.} & Entering the classroom & Entering the classroom \\
\hline & - Assalamualikum * & $\begin{array}{ll}\text { - } & \text { Assalamualikum * } \\
\text { - } & \text { Assalamualaikum warahmatullahi wabarakatu } * * \\
\text { - } & \text { Come in, please. ** }\end{array}$ \\
\hline \multirow[t]{2}{*}{2.} & Everyday greeting & Everyday greeting \\
\hline & $\begin{array}{ll}\text { - } & \text { Assalamualaikum* } \\
\text { - } & \text { Assalamualaikum } \\
& \text { warahmatullahi wabarakatu** } \\
\text { - } & \text { Good morning everybody* } \\
\text { - } & \text { How are you today?* } \\
\text { - } & \text { How is life? * }\end{array}$ & $\begin{array}{l}\text { - } \text { Assalamualaikum* } \\
\text { - } \text { Assalamualaikum warahmatullahi wabarakatu* } \\
\text { - } \text { Good morning class* } \\
\text { - } \text { Good morning students** } \\
\text { - } \text { Hood morning everybody** } \\
\text { - } \text { How is life? } *\end{array}$ \\
\hline \multirow{2}{*}{3.} & Meeting a new class & Meeting a new class \\
\hline & - Unobservable & $\begin{array}{l}\text { - } \begin{array}{l}\text { Good morning class. Is this class } \\
\text { VII.a?** }\end{array} \\
\text { - I'm your new English teacher.** } \\
\text { - } \quad \text { Let me introduce myself.** } \\
\text { - } \quad \text { Nice to meet you all.** } \\
\end{array}$ \\
\hline \multirow[t]{2}{*}{4.} & Taking the register & Taking the register \\
\hline & $\begin{array}{l}\text { - Who is missing today?* } \\
\text { - Who is absent today? }{ }^{*} \\
\text { - } \quad \text { Who doesn't come today/this }\end{array}$ & $\begin{array}{l}\text { - Ok class, attention, please. I will call the roll. Say } \\
\text { Mam or present Mam if you are here. ** }\end{array}$ \\
\hline
\end{tabular}




\begin{tabular}{|c|c|c|}
\hline & meeting?* & $\begin{array}{l}\text { - Ok class. I want to mention your names and listen } \\
\text { to me.** } \\
\text { - Who is missing today?* } \\
\text { - Who is absent today? }{ }^{*} \\
\text { - } \text { Are you all present today? } \text { - }^{*} \\
\end{array}$ \\
\hline 5. & $\begin{array}{l}\text { Being late and dealing with } \\
\text { lateness }\end{array}$ & Being late and dealing with lateness \\
\hline & - Unobservable & $\begin{array}{l}\text { - Where have you been? } \text { * }^{*} \\
\text { - Don't be late again, OK?** } \\
\text { - Come in and sit down. We already started.** } \\
\text { - Did you get up late?** } \\
\text { - Try to be on time.** }\end{array}$ \\
\hline 6. & Getting down to start & Getting down to start \\
\hline & $\begin{array}{l}\text { - Well, everybody. Let's start the } \\
\text { lesson now.* }\end{array}$ & $\begin{array}{l}\text { - Well, everybody. Let's start the lesson now.* } \\
\text { - All right class. I think we can start the lesson } \\
\text { now.** } \\
\text { - Well, students. Can we start now?** } \\
\text { - Well, it's time to start now.** }\end{array}$ \\
\hline \multicolumn{3}{|c|}{ B. Running the class } \\
\hline No. & $\begin{array}{l}\text { The Data Based on the Observation } \\
\qquad(*)\end{array}$ & The Data Based on the Interview $(* *)$ \\
\hline 1. & Beginning with revision & Beginning with revision \\
\hline & $\begin{array}{l}\text { - OK. Students, now I want to ask } \\
\text { you. What's the study last } \\
\text { meeting?* } \\
\text { - OK, who can tell the class what } \\
\text { we studied last meeting? } *\end{array}$ & $\begin{array}{l}\text { - OK. Students, now I want to ask you. What's the } \\
\text { study last meeting?* } \\
\text { - Well class, who can tell us what we discussed last } \\
\text { meeting?** } \\
\text { - OK, who can tell the class what we studied last } \\
\text { meeting?* } \\
\text { - OK, students. Do you still remember the lesson } \\
\text { last meeting?** }\end{array}$ \\
\hline 2. & Starting something new & Starting something new \\
\hline & $\begin{array}{l}\text { - Well everybody/class, our topic } \\
\text { today is about names of the } \\
\text { days.* } \\
\text { OK, class. The topic today is } \\
\text { about names of the months. * } \\
\text { Well, the topic today is still about } \\
\text { the names of the months.* }\end{array}$ & $\begin{array}{l}\text { - Well everybody/class, our topic today is about } \\
\text { names of the days.* } \\
\text { - OK, class. The topic today is about names of the } \\
\text { months. * } \\
\text { Well, the topic today is still about the names of the } \\
\text { months.* } \\
\text { OK, class. In this session you will learn about: (1) } \\
\text { to give and respond to instruction; (2) to give and } \\
\text { respond to prohibition.** }\end{array}$ \\
\hline
\end{tabular}


ELT Worldwide Vol. 4 No. 1 (2017)

Mukhlis: Classroom Management Talk in Teaching ...

\begin{tabular}{|c|c|c|}
\hline 3. & Telling the objectives & Telling the objectives \\
\hline & $\begin{array}{l}\text { - Today we are going to learn about } \\
\text { names of the days. * } \\
\text { - In this meeting we learn about } \\
\text { names of the months. * } \\
\text { - Today we are still going to learn } \\
\text { about the names of the months. } \\
\text { You are expected to be able to use } \\
\text { the word "before and after" in } \\
\text { telling the names of the months.* }\end{array}$ & $\begin{array}{l}\text { - Today we are going to learn about names of the } \\
\text { days. * } \\
\text { - In this meeting we learn about names of the } \\
\text { months. * } \\
\text { - Today we are still going to learn about the names } \\
\text { of the months. You are expected to be able to use } \\
\text { the word "before and after" in telling the names of } \\
\text { the months.* } \\
\text { - The objectives of the lesson are: (1) to give and } \\
\text { respond to instruction; and (2) to give and respond } \\
\text { to prohibition. ** }\end{array}$ \\
\hline 4. & Making things clear & Making things clear \\
\hline & 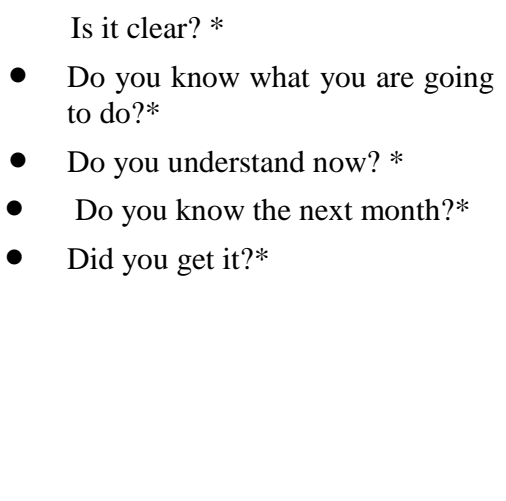 & $\begin{array}{l}\text { - Is everything clear?** } \\
\text { - } \text { Am I clear?** } \\
\text { - } \text { Is it clear?* } \\
\text { - } \text { Is it clear what I mean?** } \\
\text { - } \text { Do you know what you are going to do?* } \\
\text { - } \text { Do you understand now?* } \\
\text { - Is there any question so far?** } \\
\text { - } \text { Do you know the next month?* } \\
\text { - Did you get the point or the idea?** } \\
\text { - Did you get it?* }\end{array}$ \\
\hline \multirow[t]{2}{*}{5.} & Sequencing Activities & Sequencing Activities \\
\hline & $\begin{array}{l}\text { - Now, please observe the } \\
\text { expressions on page } 57 \text { on your } \\
\text { text book* } \\
\text { - OK. Now please mention the } \\
\text { names of the months* } \\
\text { - Then, I want to divide you into } \\
\text { some small groups then work in } \\
\text { grops.* }\end{array}$ & $\begin{array}{l}\text { - Now, please observe the expressions on page } 57 \\
\text { on your text book* } \\
\text { - OK. Now please mention the names of the } \\
\text { months* } \\
\text { - First we are going to review the last season.** } \\
\text { - Firstly, I'd like to check your homework.** } \\
\text { - Then, I want to divide you into some small } \\
\text { groups then work in grops.* }\end{array}$ \\
\hline \multirow[t]{2}{*}{6.} & Checking the progress & Checking the progress \\
\hline & $\begin{array}{l}\text { - Is there any problem? } * \\
\text { - } \quad \text { Have you finished?* } \\
\text { - } \quad \text { Have you done it? Done it?* }\end{array}$ & $\begin{array}{l}\text { - Is there any problem? } * \\
\text { - Have you finished number one to three? } * * \\
\text { - Have you finished? } * \\
\text { - Have you done it? Done it?* } \\
\text { - Please raise your hand if you got problems.** }\end{array}$ \\
\hline 7. & Taking turns & Taking turns \\
\hline
\end{tabular}




\begin{tabular}{|c|c|c|}
\hline & $\begin{array}{l}\text { - Who can ask questions? }{ }^{*} \\
\text { - Who can answer the question } 1 \text { ? } \\
\text { - } \text { OK. Next the boy students* } \\
\text { - Any questions?* } \\
\text { - Now, I want to ask you again.* } \\
\text { - Who can answer the question?* }\end{array}$ & $\begin{array}{l}\text { - Who can ask questions? } \\
\text { - Who can answer the question ? } \\
\text { - Let's give someone else a chance.** } \\
\text { - OK. Next the boy students* } \\
\text { - Now, I invite group one to present the groups' } \\
\text { discussion.** } \\
\text { - Any questions?* } \\
\text { - Now, I want to ask you again.* } \\
\text { - Who else?* }\end{array}$ \\
\hline \multicolumn{3}{|c|}{ c. Ending the lesson } \\
\hline No. & $\begin{array}{l}\text { The Data Based on the Observation } \\
\qquad(*)\end{array}$ & The Data Based on the Interview $(* *)$ \\
\hline \multirow{2}{*}{1.} & Checking the time & Checking the time \\
\hline & $\begin{array}{l}\text { - OK, class. What time is it now? } \\
* \\
\text { - Well, class. We are almost } \\
\text { finished. * }\end{array}$ & $\begin{array}{l}\text { - OK, class. What time is it now? } \\
\text { - } \quad \text { Well, class. We are almost finished. * } \\
\text { - } \quad \text { OK, how much time left? ** } \\
\text { - } \quad \text { Well, students. How much time do we have? } * *\end{array}$ \\
\hline \multirow[t]{2}{*}{2.} & Stopping work & Stopping work \\
\hline & $\begin{array}{l}\text { - OK, everybody five minutes } \\
\text { more. * } \\
\text { - } \text { OK, have you finished? * } \\
\text { - OK, time is up/time is over. * }\end{array}$ & $\begin{array}{l}\text { - OK, everybody five minutes more. } * \\
\text { - OK, have you finished? } * \\
\text { - Have you done it? } * * \\
\text { - OK, time is up/time is over. } * \\
\text { - OK, stop now. ** }\end{array}$ \\
\hline \multirow[t]{2}{*}{3.} & Setting taking home assignment & Setting taking home assignment \\
\hline & $\begin{array}{l}\text { All right, for your home work, } \\
\text { please make a conversation about } \\
\text { names of the months. * } \\
\text { OK, class. Before you go home, I } \\
\text { want to give you a home work. } \\
\text { Please work in groups to do task } \\
\text { four on page } 61 . *\end{array}$ & $\begin{array}{l}\text { - All right, for your home work, please make a } \\
\text { conversation about names of the months. * } \\
\text { - OK, class. Before you go home, I want to give } \\
\text { you a home work. Please work in groups to do } \\
\text { task four on page } 61 . * \\
\text { - OK. Class. For your assignment please write "an } \\
\text { invitation card" and submit next meeting. ** } \\
\text { - For your homework, please make some } \\
\text { instructions.** }\end{array}$ \\
\hline 4. & Making announcement & Making announcement \\
\hline & $\begin{array}{l}\text { - Attention, please. There is an } \\
\text { announcement for you all before } \\
\text { going out. Next meeting we are } \\
\text { going to discuss about names of } \\
\text { the years.* } \\
\text { - Don't forget to take your }\end{array}$ & $\begin{array}{l}\text { - Attention, please. I have some announcements } \\
\text { before you go home/go out.** } \\
\text { Attention, please. There is an announcement for } \\
\text { you all before going out. Next meeting we are } \\
\text { going to discuss about names of the years.* } \\
\text { - Don't forget to take your English book next }\end{array}$ \\
\hline
\end{tabular}


ELT Worldwide Vol. 4 No. 1 (2017)

Mukhlis: Classroom Management Talk in Teaching ...

\begin{tabular}{|c|c|c|}
\hline & English book next meeting*. & meeting*. \\
\hline 5. & Ending or closing the lesson & Ending or closing the lesson \\
\hline & $\begin{array}{l}\text { - All right class. I think enough for } \\
\text { our meeting today. Let's end the } \\
\text { lesson by reciting Alhamdulillahi } \\
\text { rabbil alamin.* } \\
\text { - } \quad \text { OK. That's all our material today. } \\
\text { Thanks for your attention* }\end{array}$ & $\begin{array}{l}\text { - Well, we have to come to the end of our class } \\
\text { today. Let's close/conclude our meeting/lesson } \\
\text { today by reciting/saying Alhamdulillahi rabbil } \\
\text { alamin.** } \\
\text { - All right class. I think enough for our meeting } \\
\text { today. Let's end the lesson by reciting } \\
\text { Alhamdulillahi rabbil alamin.* } \\
\text { - OK. That's all our material today. Thanks for } \\
\text { your attention* } \\
\text { Let's end the lesson by reciting } \\
\text { Alhamdullillahirabbilalamin.** }\end{array}$ \\
\hline \multirow[t]{2}{*}{6.} & Saying goodbye & Saying goodbye \\
\hline & $\begin{array}{l}\text { - Thank you very much for your } \\
\text { attention } \\
\text { wassalamualykum } \\
\text { warahmatullahiwabaraktu and } \\
\text { bye-bye. * } \\
\text { - Well, thanks a lot for your } \\
\text { attention and see you next } \\
\text { meeting. * } \\
\text { Thank you very much for your } \\
\text { attention and bye bye. * }\end{array}$ & $\begin{array}{l}\text { Thank you very much for your attention and } \\
\text { wassalamualykum warahmatullahiwabaraktu and } \\
\text { bye-bye. * } \\
\text { - Well, thanks a lot for your attention and see you } \\
\text { next meeting. * } \\
\text { - Thank you very much for your attention and take } \\
\text { care.** } \\
\text { - Thank you very much for your attention and bye } \\
\text { bye. * }\end{array}$ \\
\hline \multirow[t]{2}{*}{7.} & Clearing the class & Clearing the class \\
\hline & $\begin{array}{l}\text { - Take all your belongings with } \\
\text { you.* }\end{array}$ & $\begin{array}{l}\text { - } \quad \text { Take all your belongings with you.* } \\
\text { - } \quad \text { Make sure you don't leave anything behind.** } \\
\text { - } \quad \text { Please clear everything away.** }\end{array}$ \\
\hline
\end{tabular}

Note: * Observable (based on the observation and interview)

* Unobservable (based on the interview only but not observed)

\section{The Students' Understanding of the Transactional Expressions Used by the Teacher}

The second finding is about the students' understanding of the transactional expressions used by the teacher. This can be seen in the following table:

Table 2

The students' understanding of the transactional expressions used by the teacher in managing the classroom activities 
ELT Worldwide Vol. 4 No. 1 (2017)

Mukhlis: Classroom Management Talk in Teaching ...

\begin{tabular}{|c|c|c|c|c|c|c|}
\hline \multirow{3}{*}{ No } & \multirow{3}{*}{$\begin{array}{c}\text { Transactional Expressions } \\
\text { Used }\end{array}$} & \multicolumn{5}{|c|}{ Students' Understanding } \\
\hline & & $\begin{array}{c}\text { Strongly } \\
\text { Understand }\end{array}$ & Understand & $\begin{array}{c}\text { Less } \\
\text { Understand }\end{array}$ & $\begin{array}{c}\text { Don’t } \\
\text { Understand }\end{array}$ & $\begin{array}{l}\text { Strongly } \\
\text { Don't } \\
\text { Understa } \\
\text { nd }\end{array}$ \\
\hline & & $\begin{array}{l}\text { Frequency/ } \\
\text { Percentage }\end{array}$ & $\begin{array}{l}\text { Frequency/ } \\
\text { Percentage }\end{array}$ & $\begin{array}{l}\text { Frequency/ } \\
\text { Percentage }\end{array}$ & $\begin{array}{l}\text { Frequency/ } \\
\text { Percentage }\end{array}$ & $\begin{array}{l}\text { Frequency/ } \\
\text { Percentage }\end{array}$ \\
\hline$a$. & Beginning of the lesson & & & & & \\
\hline 1. & Entering the classroom & & & & & \\
\hline * & Assalamualaikum. & $22(100 \%)$ & $0(0 \%)$ & $0(0 \%)$ & $0(0 \%)$ & $0(0 \%)$ \\
\hline * & Assalamualaikum Wr.Wb. & $22(100 \%)$ & $0(0 \%)$ & $0(0 \%)$ & $0(0 \%)$ & $0(0 \%)$ \\
\hline 2. & Everyday greeting. & & & & & \\
\hline * & Assalamualaikum. & $22(100 \%)$ & $0(0 \%)$ & $0(0 \%)$ & $0(0 \%)$ & $0(0 \%)$ \\
\hline * & Assalamualaikum Wr.Wb. & $22(100 \%)$ & $0(0 \%)$ & $0(0 \%)$ & $0(0 \%)$ & $0(0 \%)$ \\
\hline$*$ & Good morning everybody. & $22(100 \%)$ & $0(0 \%)$ & $0(0 \%)$ & $0(0 \%)$ & $0(0 \%)$ \\
\hline$*$ & How are you today? & $18(81.81 \%)$ & $\begin{array}{c}4 \\
(18.18 \%)\end{array}$ & $0(0 \%)$ & $0(0 \%)$ & $0(0 \%)$ \\
\hline$*$ & How is life? & $11(50 \%)$ & $\begin{array}{c}5 \\
(22.72 \%)\end{array}$ & $0(0 \%)$ & $\begin{array}{c}6 \\
(27.27 \%)\end{array}$ & $0(0 \%)$ \\
\hline 3. & Taking the Register & & & & & \\
\hline$*$ & Who is missing today? & $12(54.54 \%)$ & $\begin{array}{c}4 \\
(18.18 \%)\end{array}$ & $0(0 \%)$ & $\begin{array}{c}6 \\
(27.27 \%)\end{array}$ & $0(0 \%)$ \\
\hline * & Who is absent today? & $18(81.81 \%)$ & $2(9.09 \%)$ & $1(4.54 \%)$ & $1(4.54 \%)$ & $0(0 \%)$ \\
\hline$*$ & $\begin{array}{l}\text { Who doesn't come } \\
\text { today/this meeting? }\end{array}$ & $8(36.36 \%)$ & $\begin{array}{c}6 \\
(27.27 \%)\end{array}$ & $2(9.09 \%)$ & $\begin{array}{c}4 \\
(18.18 \%)\end{array}$ & $2(9.09 \%)$ \\
\hline 4. & Getting down to start & & & & & \\
\hline$*$ & $\begin{array}{l}\text { Well, everybody. Let's } \\
\text { start the lesson now. }\end{array}$ & $2(9.09 \%)$ & $\begin{array}{c}10 \\
(45.45 \%)\end{array}$ & $2(9.09 \%)$ & $\begin{array}{c}6 \\
(27.27 \%)\end{array}$ & $2(9.09 \%)$ \\
\hline$b$. & Running of the class & & & & & \\
\hline 1. & Beginning with revision & & & & & \\
\hline$*$ & $\begin{array}{l}\text { OK. Students, now I want } \\
\text { to ask you. What is the } \\
\text { study last meeting? }\end{array}$ & $2(9.09 \%)$ & $\begin{array}{c}8 \\
(36.36 \%)\end{array}$ & $\begin{array}{c}4 \\
(18.18 \%)\end{array}$ & $\begin{array}{c}8 \\
(36.36 \%)\end{array}$ & $0(0 \%)$ \\
\hline$*$ & $\begin{array}{l}\text { OK class, who can tell us } \\
\text { what we discussed last }\end{array}$ & $2(9.09 \%)$ & $\begin{array}{c}8 \\
(36.36 \%)\end{array}$ & $\begin{array}{c}4 \\
(18.18 \%)\end{array}$ & $\begin{array}{c}6 \\
(27.27 \%)\end{array}$ & $2(9.09 \%)$ \\
\hline
\end{tabular}


ELT Worldwide Vol. 4 No. 1 (2017)

Mukhlis: Classroom Management Talk in Teaching ...

\begin{tabular}{|c|c|c|c|c|c|c|}
\hline & meeting? & & & & & \\
\hline 2. & Starting something new & & & & & \\
\hline$*$ & $\begin{array}{l}\text { Well everybody / class, } \\
\text { our topic today is about } \\
\text { names of the days. }\end{array}$ & $4(18.18 \%)$ & $\begin{array}{c}14 \\
(63.63 \%)\end{array}$ & $2(9.09 \%)$ & $2(9.09 \%)$ & $0(0 \%)$ \\
\hline$*$ & $\begin{array}{l}\text { OK, class. The topic today } \\
\text { is about names of the } \\
\text { months. }\end{array}$ & $4(18.18 \%)$ & $\begin{array}{c}14 \\
(63.63 \%)\end{array}$ & $2(9.09 \%)$ & $2(9.09 \%)$ & $0(0 \%)$ \\
\hline$*$ & $\begin{array}{l}\text { The topic today is still } \\
\text { about names of the months }\end{array}$ & $\begin{array}{c}14 \\
(63.63 \%)\end{array}$ & $\begin{array}{c}4 \\
(18.18 \%)\end{array}$ & $2(9.09 \%)$ & $2(9.09 \%)$ & $0(0 \%)$ \\
\hline 3. & \multicolumn{6}{|l|}{ Telling the objectives } \\
\hline$*$ & $\begin{array}{l}\text { Well everybody, our topic } \\
\text { today is about names of } \\
\text { the days. }\end{array}$ & $4(18.18 \%)$ & $\begin{array}{c}14 \\
(63.63 \%)\end{array}$ & $2(9.09 \%)$ & $2(9.09 \%)$ & $0(0 \%)$ \\
\hline$*$ & $\begin{array}{l}\text { OK, class. The topic today } \\
\text { is about names of the } \\
\text { months. }\end{array}$ & $4(18.18 \%)$ & $\begin{array}{c}14 \\
(63.63 \%)\end{array}$ & $2(9.09 \%)$ & $2(9.09 \%)$ & $0(0 \%)$ \\
\hline$*$ & $\begin{array}{l}\text { Today we are still going to } \\
\text { learn about the names of } \\
\text { the months. You are } \\
\text { expected to be able to use } \\
\text { the word "before and } \\
\text { after" in telling the names } \\
\text { of the months. }\end{array}$ & $4(18.18 \%)$ & $\begin{array}{c}8 \\
(36.36 \%)\end{array}$ & $2(9.09 \%)$ & $\begin{array}{c}6 \\
(27.27 \%)\end{array}$ & $2(9.09 \%)$ \\
\hline 4. & \multicolumn{6}{|l|}{ Making things clear? } \\
\hline$*$ & Is it clear? & $\begin{array}{c}10 \\
(45.45 \%)\end{array}$ & $\begin{array}{c}10 \\
(45.45 \%)\end{array}$ & $2(9.09 \%)$ & $0(0 \%)$ & $0(0 \%)$ \\
\hline$*$ & Do you understand now? & $\begin{array}{c}10 \\
(45.45 \%) \\
\end{array}$ & $\begin{array}{c}10 \\
(45.45 \%) \\
\end{array}$ & $2(9.09 \%)$ & $0(0 \%)$ & $0(0 \%)$ \\
\hline$*$ & $\begin{array}{l}\text { Do you now the next } \\
\text { month? }\end{array}$ & $2(9.09 \%)$ & $\begin{array}{c}12 \\
(54.54 \%) \\
\end{array}$ & $2(9.09 \%)$ & $\begin{array}{c}4 \\
(18.18 \%) \\
\end{array}$ & $2(9.09 \%)$ \\
\hline * & Did you get it/Get it? & $\begin{array}{c}12 \\
(54.54 \%)\end{array}$ & $\begin{array}{c}6 \\
(27.27 \%) \\
\end{array}$ & $2(9.09 \%)$ & $2(9.09 \%)$ & $0(0 \%)$ \\
\hline 5. & \multicolumn{6}{|l|}{ Sequencing activities } \\
\hline$*$ & $\begin{array}{l}\text { Now, please observe the } \\
\text { expressions on page } 57 \text { on } \\
\text { your text book. }\end{array}$ & $5(22.72 \%)$ & $\begin{array}{c}9 \\
(40.90 \%)\end{array}$ & $\begin{array}{c}3 \\
(13.63 \%)\end{array}$ & $5(22.72 \%)$ & $0(0 \%)$ \\
\hline$*$ & $\begin{array}{l}\text { OK. Now please mention } \\
\text { the names of the months. }\end{array}$ & $11(50 \%)$ & $\begin{array}{c}6 \\
(27.27 \%) \\
\end{array}$ & $1(4.54 \%)$ & $\begin{array}{c}4 \\
(18.18 \%) \\
\end{array}$ & $0(0 \%)$ \\
\hline$*$ & $\begin{array}{l}\text { Then, I want to divide you } \\
\text { into some small groups } \\
\text { then work in groups. }\end{array}$ & $2(9.09 \%)$ & $\begin{array}{c}12 \\
(54.54 \%)\end{array}$ & $0(0 \%)$ & $5(22.72 \%)$ & $3(13.63 \%)$ \\
\hline 6. & \multicolumn{6}{|l|}{ Checking Progress } \\
\hline
\end{tabular}


ELT Worldwide Vol. 4 No. 1 (2017)

Mukhlis: Classroom Management Talk in Teaching ...

\begin{tabular}{|c|c|c|c|c|c|c|}
\hline$*$ & Is there any problem? & $\begin{array}{c}16 \\
(72.72 \%) \\
\end{array}$ & $\begin{array}{c}6 \\
(23.08 \%) \\
\end{array}$ & $0(0 \%)$ & $0(0 \%)$ & $0(0 \%)$ \\
\hline$*$ & Have you finished? & $22(100 \%)$ & $0(0 \%)$ & $0(0 \%)$ & $0(0 \%)$ & $0(0 \%)$ \\
\hline$*$ & $\begin{array}{l}\text { Have you done it?/ Done } \\
\text { it? }\end{array}$ & $9(40.90 \%)$ & $\begin{array}{c}10 \\
(45.45 \%)\end{array}$ & $2(9.09 \%)$ & $1(4.54 \%)$ & $0(0 \%)$ \\
\hline 7. & Taking turns & & & & & \\
\hline$*$ & Who can ask questions? & $7(31.81 \%)$ & $\begin{array}{c}10 \\
(45.45 \%)\end{array}$ & $2(9.09 \%)$ & $\begin{array}{c}3 \\
(13.63 \%)\end{array}$ & $0(0 \%)$ \\
\hline$*$ & $\begin{array}{l}\text { Who can answer the } \\
\text { question? }\end{array}$ & $7(31.81 \%)$ & $\begin{array}{c}10 \\
(45.45 \%) \\
\end{array}$ & $2(9.09 \%)$ & $\begin{array}{c}3 \\
(13.63 \%) \\
\end{array}$ & $0(0 \%)$ \\
\hline$*$ & $\begin{array}{l}\text { OK. Next the boy } \\
\text { students. }\end{array}$ & $\begin{array}{c}10 \\
(45.45 \%)\end{array}$ & $\begin{array}{c}12 \\
(54.54 \%)\end{array}$ & $0(0 \%)$ & $0(0 \%)$ & $0(0 \%)$ \\
\hline$*$ & Any questions? & $\begin{array}{c}10 \\
(45.45 \%)\end{array}$ & $\begin{array}{c}12 \\
(54.54 \%)\end{array}$ & $0(0 \%)$ & $0(0 \%)$ & $0(0 \%)$ \\
\hline$*$ & $\begin{array}{l}\text { Now, I want to ask you } \\
\text { again }\end{array}$ & $\begin{array}{c}10 \\
(45.45 \%)\end{array}$ & $\begin{array}{c}12 \\
(54.54 \%)\end{array}$ & $0(0 \%)$ & $0(0 \%)$ & $0(0 \%)$ \\
\hline$*$ & Who else? & $2(9.09 \%)$ & $\begin{array}{c}12 \\
(54.54 \%)\end{array}$ & $0(0 \%)$ & $5(22.72 \%)$ & $3(13.63 \%)$ \\
\hline$c$. & Ending the lesson & & & & & \\
\hline 1. & Checking the time & & & & & \\
\hline$*$ & $\begin{array}{l}\text { Ok, class. What time is it } \\
\text { now? }\end{array}$ & $5(22.72 \%)$ & $\begin{array}{c}10 \\
(45.45 \%)\end{array}$ & $1(4.54 \%)$ & $5(22.72 \%)$ & $1(4.54 \%)$ \\
\hline$*$ & $\begin{array}{l}\text { Well, class. We are almost } \\
\text { finished. }\end{array}$ & $8(30.77 \%)$ & $\begin{array}{c}9 \\
(40.90 \%)\end{array}$ & $0(0 \%)$ & $\begin{array}{c}4 \\
(18.18 \%)\end{array}$ & $1(4.54 \%)$ \\
\hline 2. & Stopping work & & & & & \\
\hline$*$ & $\begin{array}{l}\text { Ok, everybody. Five } \\
\text { minutes more. }\end{array}$ & $\begin{array}{c}10 \\
(45.45 \%)\end{array}$ & $\begin{array}{c}12 \\
(54.54 \%)\end{array}$ & $0(0 \%)$ & $0(0 \%)$ & $0(0 \%)$ \\
\hline$*$ & Have you finished? & $22(100 \%)$ & $0(0 \%)$ & $0(0 \%)$ & $0(0 \%)$ & $0(0 \%)$ \\
\hline$*$ & Ok, time is up & $11(50 \%)$ & $\begin{array}{c}6 \\
(27.27 \%)\end{array}$ & $1(4.54 \%)$ & $\begin{array}{c}4 \\
(18.18 \%)\end{array}$ & $0(0 \%)$ \\
\hline 3. & $\begin{array}{l}\text { Setting taking home } \\
\text { assignment }\end{array}$ & & & & & \\
\hline$*$ & $\begin{array}{l}\text { Ok, class. Before you go } \\
\text { home, I } \\
\text { give you a home work. } \\
\text { Please work in groups to } \\
\text { do activity } \\
\text { on page } 61 .\end{array}$ & $0(0 \%)$ & $\begin{array}{c}8 \\
(36.36 \%)\end{array}$ & $\begin{array}{c}4 \\
(18.18 \%)\end{array}$ & $\begin{array}{c}8 \\
(36.36 \%)\end{array}$ & $2(9.09 \%)$ \\
\hline$*$ & $\begin{array}{l}\text { All right, for you home } \\
\text { work, please make a } \\
\text { conversation about names } \\
\text { of the months. }\end{array}$ & $5(22.72 \%)$ & $\begin{array}{c}10 \\
(45.45 \%)\end{array}$ & $1(4.54 \%)$ & $5(22.72 \%)$ & $1(4.54 \%)$ \\
\hline 4. & Making announcement & & & & & \\
\hline
\end{tabular}


ELT Worldwide Vol. 4 No. 1 (2017)

Mukhlis: Classroom Management Talk in Teaching ...

\begin{tabular}{|c|c|c|c|c|c|c|}
\hline * & $\begin{array}{l}\text { Attention please. There is } \\
\text { a announcement for you } \\
\text { all before going out. Next } \\
\text { meeting we are going to } \\
\text { discuss about names of the } \\
\text { years. }\end{array}$ & $5(22.72 \%)$ & $\begin{array}{c}8 \\
(36.36 \%)\end{array}$ & $1(4.54 \%)$ & $\begin{array}{c}7 \\
(31.81 \%)\end{array}$ & $1(4.54 \%)$ \\
\hline$*$ & $\begin{array}{l}\text { Don't forget to take your } \\
\text { English book next } \\
\text { meeting. }\end{array}$ & $11(50 \%)$ & $\begin{array}{c}6 \\
(27.27 \%)\end{array}$ & $1(4.54 \%)$ & $\begin{array}{c}4 \\
(18.18 \%)\end{array}$ & $0(0 \%)$ \\
\hline 5. & Ending the lesson & & & & & \\
\hline$*$ & $\begin{array}{l}\text { All right class. I think } \\
\text { enough for our meeting } \\
\text { today. Let's end the lesson } \\
\text { by reciting Alhamdulillahi } \\
\text { Robbil Alamin }\end{array}$ & $11(50 \%)$ & $\begin{array}{c}6 \\
(27.27 \%)\end{array}$ & $1(4.54 \%)$ & $\begin{array}{c}4 \\
(18.18 \%)\end{array}$ & $0(0 \%)$ \\
\hline$*$ & $\begin{array}{l}\text { Ok, that's all our material } \\
\text { today. Thanks for your } \\
\text { attention. }\end{array}$ & $11(50 \%)$ & $\begin{array}{c}6 \\
(27.27 \%)\end{array}$ & $1(4.54 \%)$ & $\begin{array}{c}4 \\
(18.18 \%)\end{array}$ & $0(0 \%)$ \\
\hline 6. & Saying goodbye & & & & & \\
\hline$*$ & $\begin{array}{l}\text { Thank you very much for } \\
\text { your attention and } \\
\text { wassalamualaikum } \\
\text { warahmatullahiwabarakat } \\
\text { uh. Bye now. }\end{array}$ & $\begin{array}{c}10 \\
(45.45 \%)\end{array}$ & $\begin{array}{c}12 \\
(54.54 \%)\end{array}$ & $0(0 \%)$ & $0(0 \%)$ & $0(0 \%)$ \\
\hline$*$ & $\begin{array}{l}\text { Thank you very much for } \\
\text { your attention and bye- } \\
\text { bye. }\end{array}$ & $22(100 \%)$ & $0(0 \%)$ & $0(0 \%)$ & $0(0 \%)$ & $0(0 \%)$ \\
\hline 7. & Clearing the class & & & & & \\
\hline$*$ & $\begin{array}{l}\text { Take all your belongings } \\
\text { with you. }\end{array}$ & $0(0 \%)$ & $\begin{array}{c}10 \\
(45.45 \%)\end{array}$ & $0(0 \%)$ & $\begin{array}{c}10 \\
(45.45 \%)\end{array}$ & $2(9.09 \%)$ \\
\hline
\end{tabular}

In "entering the classroom" the teacher used the transactional expressions: "Assalamualikum, and Assalumualaikum warahmatulllahi wabarakatu". The result of analysis of the questionnaires showed that from 22 students, one hundred percent (100\%) or all of them chose the option "strongly understand" toward the expressions used by the teacher. It means that the students understood the expressions well and strongly.

In the stage of "everyday greeting", all students (100\%) chose "strongly understand" in responding to the expression of "Assalamualaikum warahmatullahi wabaraktu, good morning class, and how are you today?". Then, the expression of "how is life", eleven students chose "strongly understand" (50\%), five students stated "understand" (22.72\%) and six students chose "less understand" (27.27\%).

The third stage of this phase was "taking the register". In this stage, twelve (54.54\%) students chose "strongly understand", four students (18.18\%) chose "understand", and six 
(27.27) students chose "less understand" to the expression of "who is missing today?". Next expression used was "who is absent today?". Eighteen students $(81.81 \%)$ chose "strongly understand", two students (9.09\%) stated "understand", one student (4.54\%) said "less understand" and one student (4.54\%) said "less understand". The third expression used was "who doesn't come in this meeting? "From twenty two students, eight of them (36.36\%) chose "strongly understand", $6(27.27 \%)$ stated "understand", two of them $(9.09 \%)$ said "less understand", four of them chose "don't understand", and two students $(9.009 \%)$ stated "strongly don't understand".

In "getting down to start", the teacher only used the expression of "well everybody, let's start the lesson now" during the observation took place. In this case, there were two students $(9.09 \%)$ chose the option "strongly understand", ten students $(45.45 \%)$ chose "understand", two of them (9.09\%) stated "less understand", six of them $(27.27 \%)$ stated "don't understand, and two students (9.09\%) chose "strongly don't understand".

The second phase of classroom activity was the running of the class. The data (transactional expressions) used by the teacher were classified into: (1) beginning with revision, (2) starting something new, (3) telling the objectives, (4) making things clear or checking the students' understanding, (5) sequencing activities, (6) checking progress, and (7) taking turns, (Rasyid, 2012:18-19). All the stages involved transactional expressions used by the teacher in teaching English in the class.

The first stage of the classroom activity in the running of the class was "beginning with revision". The first expression was "Ok students, now I want to ask you. What's the study last meeting". There were two students $(9.09 \%)$ stated "strongly understand". There were ten students $(45.45 \%)$ chose "understand", two students (9.09\%) stated "less understand", six students (27.27\%) chose don't understand, and two students $(9.09 \%)$ stated "strongly don't understand". The second expression that was used by the teacher was "Ok class who can tell us what we discussed last meeting?". The students' understanding related to this expression was described as follows: There were two (9.09\%) students chose the option "strongly understand", eight students (36.36\%) stated "understand", four students (18.18\%) chose "less understand", six students (27.27\%) chose "don't understand", and two $(9.09 \%)$ students chose the option "strongly don't understand".

Next stage was "starting something new". First expression used in this stage was "well everybody, our topic today is about names of the days". Related to this expression, there were four $(18.18 \%)$ students chose "strongly understand", fourteen students (63.63\%) students stated "understand", two students $(9.09 \%)$ chose "less understand", two students $(9.09 \%)$ stated "don't understand", and none $(0 \%)$ chose "strongly don't understand". The second expression was "OK class, the topic today is about names of the months." In this expression, there were four $(18.18 \%)$ students chose "strongly understand", fourteen students $(63.63 \%)$ students stated "understand", two students $(9.09 \%)$ chose "less understand", two students $(9.09 \%)$ stated "don't understand", and no students $(0 \%)$ chose "strongly don't understand" The third expression was "well, today we are still going to discuss about names of the months". Related to this expression, there were fourteen students $(63.63 \%)$ students chose "strongly understand", four (18.18\%) students stated 
"understand", two students (9.09\%) chose "less understand", two students $(9.09 \%)$ stated "don't understand", and none of them $(0 \%)$ chose "strongly don't understand".

In "telling the objectives", the teacher used three kinds of transactional expressions. The first expression was "today we are going to learn about names of the days." The second expression was "in this meeting, we learn about names of the months". Related to these expressions, there were four $(18.18 \%)$ students chose "strongly understand", fourteen students (63.63\%) students stated "understand", two students $(9.09 \%)$ chose "less understand", two students $(9.09 \%)$ stated "don't understand", and no students $(0 \%)$ chose "strongly don't understand". The third expression was "today we are still going to learn about names of the months. You are expected to be able to use the word "before and after" in telling the names of the months". There were four (18.18\%) students chose "strongly understand", eight students (36.36\%) students stated "understand", two students $(9.09 \%)$ chose "less understand", six students $(27.27 \%)$ stated "don't understand", and two students $(9.09 \%)$ chose "strongly don't understand".

In "making things clear/checking the students' understanding," the teacher used some transactional expressions. The first expression was "is it clear?" The second was "do you understand now?" The description of the students' understanding to these expressions as follows: ten students $(45.45 \%)$ chose "strongly understand", ten students $(45.45 \%)$ also stated "understand", two students $(9.09 \%)$ chose "less "understand", and no student chose "don't understand and strongly don't understand". The third expression was "do you know the next month?". Two students $(9.09 \%)$ chose "strongly understand", twelve students $(54.54 \%)$ chose "understand", Two students (9.09\%) chose "less understand", four students (18.18\%) chose "don't understand", and Two students $(9.09 \%)$ chose "strongly don't understand". The fourth expression was "did you get it?". There were twelve students $(54.54 \%)$ chose "strongly understand", six students $(27.27 \%)$ stated "understand", two students (9.09\%) chose "less understand", and two students (9.09\%) stated "don't understand".

The next stage of classroom activity in the running of the class was "sequencing activities". The teacher used three kinds of expressions during the observation done by the researcher took place. The expressions were: "Now, please observe the expressions on page 57 on your text book. Ok, now please mention names of the months. Then, I want to divide you into some small groups then work in groups. For the first expression, there were five students $(22.72 \%)$ chose "strongly understand", nine students $(40.90 \%)$ chose "understand", three students (13.63\%) stated "less understand", and five students (2.72\%) stated "don't understand". For the second transactional expression, there were eleven students $(50 \%)$ chose "strongly understand", six students $(27.27 \%)$ stated "understand", one student $(4.54 \%)$ chose "less understand", and for students $(18.18 \%)$ stated "don't understand. Then for the third transactional expression, there were two students $(9.09 \%)$ chose "strongly understand", twelve students (54.54\%) chose "understand", no student $(0 \%)$ stated "less understand", and five students $(22.72 \%)$ chose "don't understand".

Then, in "checking the progress", the teacher used some transactional expressions. The first was "is there any problem?" The students understanding to this expression could be 
described as follow: there were sixteen students (72.72\%) stated "strongly understand", six students $(27.27 \%)$ chose "understand), and no one stated "less understand, don't understand, strongly don't understand". Next transactional expression was "have you finished?". There were twenty two or all students $(100 \%)$ stated "strongly understand" about this expression. Then, third transactional expression was "have you done it? Done it?".There were nine students $(40.90 \%)$ chose "strongly understand", ten students (45.45\%) chose "understand", two students $(9.09 \%)$ stated "less understand", and only one student $(4.54 \%)$ chose "don't understand".

The last stage was "taking turns". In this stage, the teacher used some transactional expressions as follows: "Who can ask questions? Who can answer question number one? $\mathrm{OK}$, next the boy students. Is there any question? Now I want to ask you again. Who else? Who can answer the questions? All the expressions were used by the teacher to vary her expressions in managing the classroom activity.

For the first and the second transactional expressions, there were seven students (31.18) chose "strongly understand", ten students (45.4.5\%) stated "understand", two students $(9.09 \%)$ chose "less understand", and three students (13.63\%) stated "don't understand". For the third, the fourth and the fifth expressions, there were ten students $(45.45 \%)$ chose "strongly understand", twelve students (54.54\%) stated "understand to the expressions used and none of them stated "less understand, don't understand, and strongly don't understand".

The last phase of the classroom activities was "The end of the lesson or ending the lesson". At the end of the lesson, the data of management talk (transactional expressions) used by the teacher were classified into: (1) checking the time, (2) setting taking home assignment, (3) stopping work, (4) making announcement, (5) ending the lesson, (6) saying good bye, and (7) clearing the class (Rasyid, 2012: 19).

The first stage of the end of the lesson activity was "checking the time". In this stage, the teacher used two transactional expressions during the observation took place. The expressions were: "Ok class, what time is it now? Well, class we are almost finished". Related to the students' understanding toward the first transactional expression, there were five students $(22.72 \%)$ stated "strongly understand", ten students $(45.45 \%)$ chose "understand", one student chose "less understand", five students chose "don't understand", and one student stated "strongly don't understand". For the second transactional expression, there were eight students $((30.77 \%)$ stated "strongly understand", nine students $(40.90 \%)$ chose "understand", four students $(18.18 \%)$ stated "don't understand", and one student (4.54\%) stated "strongly don't understand".

The next stage of the end of the lesson activity was "stopping work". The teacher applied three kinds of expression in this stage. The expressions as follows: "Ok everybody, five minutes more. Ok, have you finished? Well, time is up/over". For the first transactional expression, there were ten students $(45.45 \%)$ stated "strongly understand", and twelve students $(54.54 \%)$ stated "understand". 
For the second transactional expression, there were twenty two students (100\%) stated strongly understand. For the third expression, there were eleven students $(50 \%)$ chose "strongly understand", six students (27.27\%) stated "understand", one student (4.54\%) chose "less understand", and four (18.18\%) students stated "don't understand".

The third stage was "setting taking home assignment". Based on the observation, she (the subject) used the following transactional expressions to give her students home works. The expressions were: "Ok class, I want to give you a home work before you go home. Please work in groups to do task four on page 61" and "All right for your homework, please make a conversation about names of the months". Related to the first transactional expression, there were eight students (36.36\%) stated "understand", four students (18.18\%) stated "less understand", eight students (36.36\%) stated "don't understand", and two students $(9.09 \%)$ chose "strongly don't understand". For the second transactional expression, there were five students $(22.72 \%)$ stated "strongly understand", ten students $(45.45 \%)$ chose ""understand", one student (4.54\%) stated "less understand", five students $(22.72 \%)$ chose "don't understand", and one student (4.54\%) stated "strongly don't understand".

The fourth stage of this phase of classroom activity was "making announcement". There were two transactional expressions used by the teacher in this stage. The expressions were as follows: "Attention, please! There is announcement for you all before going out. Next meeting we are going to discuss about names of the years. Don't forget to take your English book next meeting". For the first transactional expression, there were five students $(22.72 \%)$ chose "strongly understand", eight students $(36.36 \%)$ stated "understand", one student (4.54\%) stated "less understand", seven students (31.81\%) chose "don't understand", and one student (4.54\%) stated "strongly don't understand". For the second expression, there were eleven students (50\%) chose "strongly understand", six students (27.27\%) stated "understand", one student (4.54\%) stated "less understand", four students $(18.18 \%)$ chose "don't understand", and no student $(0 \%)$ stated "strongly don't understand".

The next stage of this phase was "ending the lesson or closing the lesson". There were only two expressions taken by the teacher in this stage. The expressions were: "Well, I think enough our meeting today. Let's end the lesson by reciting Alhamndullillahirabbilalamin. Ok, that's all our material today. Thanks for your attention". Both transactional expressions were understood by the students and gave benefit to them.

The sixth stage was "saying good bye". In this case, the teacher used the transactional expressions to take leave with the students at the end of the lesson. The expressions used were as follows: "Thank you very much for your attention and wassalamualaikum warahmatullahi wabaraktu and bye-bye." Well, thanks a lot for your attention and see you next meeting". For the first and the second transactional expressions, there were ten students $(45.45 \%)$ chose "strongly understand", and twelve students $(54.54 \%)$ stated "understand". For the third transactional expression, all the students $(100 \%)$ stated "strongly understand". 
The last stage or the last activity of this phase was "clearing the class". The transactional expressions used by the teacher in this stage to manage the class to remind or to make sure that all the students do not leave anything behind before going out from the classroom or before going home. There was only one transactional expression used by the teacher in this stage when the observation taken. The expression was "take all your belongings with you". It was understood well by the students and it means it gave benefit to the students.

\section{Transactional Expressions which give Benefit to the Students}

In the beginning of the lesson, the data (transactional expressions) used by the teacher were classified into: (1) entering the class, (2) everyday greeting, (3) meeting a new class (optional), (4) taking the register, (5) being late and dealing with the lateness, and (6) getting down to start (Rasyid, 2012:18).

In "entering the classroom" and "everyday greeting", the transactional expressions were understood well by the students. It was supported by the students' respond and the students' understanding of the expressions used. The data analysis show that all students (twenty two students) or one hundred percent students stated "strongly understand". It means they gave benefit to the students.

In "taking the register", there were three transactional expressions that gave benefit to the students. The first expression was "who is missing today?". This transactional expression gave benefit to the students where twelve $(54.54 \%)$ students chose "strongly understand", four students (18.18\%) chose "understand", and six (27.27) students chose "less understand" to this expression. The transactional expression that gave benefit to the students in the stage of "getting down to start "was "well everybody, let's start the lesson now".

The second phase of classroom activity was the running of the class. The data (transactional expressions) used by the teacher were classified into: (1) beginning with revision, (2) starting something new, (3) telling the objectives, (4) making things clear or checking the students' understanding, (5) sequencing activities, (6) checking progress, and (7) taking turns (Rasyid, 2012:18-19). Most of the transactional expressions used in all stages of in this phase were beneficial to the students.

The last phase of the classroom activities was "The end of the lesson or ending the lesson". The first stage of the end of the lesson activity was "checking the time". In this stage, there were two transactional expressions which gave benefit to the students. The next stage was "stopping work". There were three transactional expressions that gave benefit. The third stage was "setting taking home assignment". The transactional expressions that gave benefits were three transactional expressions.

The next stages were "making announcement, closing the lesson, saying good bye, and clearing the classroom". All transactional expressions used in those stages were beneficial to the students. 


\section{DISCUSSION}

The above findings show the transactional expressions used by the teacher in managing the classroom activities, the students' understanding of those transactional expressions, and the transactional expressions which gave benefit to the students. There were three kinds of phases of the classroom activity (classroom activity-based). The data are the management talk which were used by the teacher in beginning the lesson, running the class, and ending the class or lesson. This finding supported proceeding finding that was found by Rasyid (2012) about classroom management talk (activity-based) that consisted of three phases of activities and covers some stages and language functions in every phase of learning activities in the class.

In the beginning of the lesson, the transactional expressions used are classified into some stages as language functions as follows: (1) entering the class, (2) everyday greeting, (3) meeting a new class (optional), (4) taking the register, (5) being late and dealing with the lateness, and (6) getting down to start, Rasyid (2012:18). Basically, the my findings are the same, mostly the stages of management talk mentioned above were the same, except in the third stage and the fifth stage, namely "meeting a new class and being late and dealing with the lateness are different or not observed when I observed the teacher in teaching English in the class. A similar finding from Doff (1993) in Rasyid (2012: 14) also supported this finding. Doff divided the management talk into some language functions and three of them were: (1) greeting, (2) checking attendance (taking the register), and talk to students or getting down to start.

In the phase of running of the class the data (transactional expressions) used by the lecturer or teacher were classified into: (1) beginning with revision, (2) starting something new, (3) telling the objectives, (4) making things clear or checking the students' understanding, (5) sequencing activities, (6) checking progress, and (7) taking turns, Rasyid (2012: 18-19). It was relevant with my finding. The researcher found some particular transactional expressions used by the teacher in all language functions in all the stages stated above. Doff in Rasyid (2012:14) also classified some language functions used in the running of the class and two of them were similar or same with this finding, namely, (1) asking to do something or sequencing activities, and (2) giving turn or taking turns.

The third phase of the classroom activities was "The end of the lesson or ending the lesson". At the end of the lesson, the data of management talk (transactional expressions) used by the teacher were classified into: (1) checking the time, (2) setting taking home assignment, (3) stopping work, (4) making announcement, (5) ending the lesson, (6) saying good bye, and (7) clearing the class. It was matched with the finding that was found by Rasyid (2012). He classified the transactional expressions used by the lecturer or teacher into seven stages as the researcher found.

Based on all the stages of learning activities mentioned above, the teacher used at least one or some transactional expressions as language functions as were depicted in the findings description, except in the stage of "meeting a new class and being late and 
dealing with the lateness". Overall, it can be interpreted that the transactional expressions applied by the teacher were understood well by the students and gave benefit to them. It means that transactional expressions used by the teacher were effective and they could be a good input to the students to acquire the language or the management talk produced by the teacher. It was relevant with the theory and finding that was found by Rasyid (2012: 27) that students had good theoretical acquisition of the classroom management talk in English (mean score:78.66 which is categorized Good). The better and more effective the management talks used by the teacher, the better theoretical language acquisition expected. The same finding and theory from Lei (2009:1) also supported this finding that good teacher talk lays focus on how effectively it could promote genuine communication in the classroom.

From all the stages of each phase of learning activities, the teacher only use a few transactional expressions. As Lei (2009: 1) stated that good teacher talk meant little teacher talk, since too much teacher talk deprived students of opportunities to speak. However, it should be the "quality" rather than the "quantity" that counts. A good teacher talk should be judged by how effectively it was able to facilitate learning and promote communicative interaction in the classroom. In this case, most of the students understood about the transactional expression used by the teacher and it means that it gave benefit to the students. These transactional expressions were simple and effective based on the data description in the finding. It means they were understood by the students and beneficial for them. It was relevant with Breines (2002) statement that one of characteristics of teacher talk which function as a language input is "the teacher talk should be shorter, simpler, slower, and clearer speech".

\section{Limitations and Conclusions}

This paper has discussed many important transactional expressions based on the stages of learning activities. This is an important note to be remembered that being a teacher needs to effective transactional expressions or management talk to manage the learning activities effectively and efficiently to give a good language acquisition to the students.

This paper has also discussed the important transactional expressions as language functions which gave benefit to the students in gaining language input. Based on the research findings and discussion above, I conclude the result of this research as follows: (1) the transactional expressions which were used by the teacher in managing the classroom activities are classified into three kinds of phases of the classroom activity (classroom activity-based). The data are the management talk used by the teacher in beginning the lesson, running the class, and ending the class or lesson. In the beginning of the class, the data (transactional expressions) used by the teacher are classified into: (1) entering the class, (2) everyday greeting, (3) meeting a new class (optional), (4) taking the register, (5) being late and dealing with the lateness, and (6) getting down to start. When the researcher observed the subject in the class, the teacher did not use any transactional expression in the stage of "meeting a new class" because that was not the first meeting the teacher taught the students at the time. The same case happened to the stage of "being late and dealing with the lateness". The teacher did not use any transactional expression in this stage because there was not any student who came late during the observation took place. 
In the running of the class, the data (transactional expressions) used by the teacher and the students' responses are classified into: (1) beginning with revision, (2) starting something new, (3) telling the objectives, (4) making things clear or checking the students' understanding, (5) sequencing activities, (6) checking progress, and (7) taking turns. At the end of the lesson, the data (transactional expressions) used by the teacher and the students' responses are classified into: (1) checking the time, (2) setting taking home assignment, (3) stopping work, (4) making announcement, (5) ending the lesson, (6) saying good bye, and (7) clearing the class; (2) mostly the transactional expressions applied by the teacher in managing the classroom activities were understood by the students. It was proved by the frequency and the percentage of the students' understanding of each transactional expression of each stage based on the three phases of classroom activities as they have been stated at findings and discussion parts; and (3) the transactional expressions used by the teacher in managing classroom activities in beginning the lesson, running the class, and ending the lesson, mostly give benefit. The transactional expressions mostly give positive contribution in running the activities in teaching and learning process.

Apart from the above findings, this study has limitations. The study should be continued by observing more on teachers and students interactions in the class. As this study only observed about the phase of language activities (activity-based) based on the proceeding findings which were found by Rasyid (2012). This study applied an open ended questionnaire to know about the students' understanding of the transactional expressions used by the teacher in which students were asked to state or put a checklist what they know or understand about the transactional expressions used but not based on the observation. The observation was only used to get the data about the transactional expressions used by the teacher. Further studies are recommended to develop as many language functions as they can find such as asking for opinion, agreeing, reviewing the materials at the end of the lesson, reflecting the students' feeling and achievement, and so forth.

\section{REFERENCES}

Allwright, D. \& Kathleen M. Bailey. 1991. Focus on the Language Classroom: An Introduction to Classroom Research for Language Teachers. USA: Cambridge University Press.

Brown, H. D. 2001. Pinciples of Language Learning and Teaching. New Jersey: Prentice Hall. Inc.

Chaudron, Craig. 1988. Second Language Classrooms. Research on Teaching and Learning. USA: Cambridge University Press.

Chullen Richard. 1997. Teacher talk and the classroom context. Research on English Learning and Teaching. British: Canterbury Christ Church College. Press.

Kizlik, Bob (2012). Classroom Management, Management of Student Conduct, Effective Praise Guidelines, and a Few Things to Know About ESOL Thrown in for Good 
Measure. Online Journal, 2007-2012: http://www.adprima.com/managing.htm. Accessed on October $25^{\text {th }} 2012$.

Kogut and Silver (2009). Teacher Talk, Pedagogical Talk and Classroom Activities: Another Look. English Language Teaching Journal, 15 (1), 1-18.

Lei Xuelian (2009). Communicative Teacher Talk in the English Classroom. English Language Teaching Journal 2 (1), 1-7.

Lemke, J.L. 1985."Perspectives for Studying Classroom Talk." Using Language in the Classroom. Geelong. Vic: Deakin University Press.

Pektova Mariana M., 2009. Classroom discourse and Teacher talk influences on English language learner students' mathematics experiences. A dissertation submitted in partial fulfillment of the requirements for the degree of Doctor of Philosophy Department of Mathematics Education College of Education University of South Florida.

Prabhu, N. S.1991. The Learner's Effort in the Language Classroom. In Eugenius Sadtono (Ed.). Language Acquisition and the Second/ Foreign Language classroom ( pp 49 - 58). Singapore: SEAMEO Regional Language Centre.

Rasyid, Muhammad Amin. 2012. Bahasa Pengelolaan Kelas Berbasis Tahapan Kegiatan Kelas. Makassar. Badan Penerbit UNM.

Walsh Steve, 2012. Conceptualizing Classroom Interactional Competence. NovitasROYAL (Research on Youth and Language) Journal, 6 (1), 1-14.

Wajnryb, Ruth. 1993. Classroom Observation Tasks: a resource book for language teachers and trainers. New York: Cambridge University Press.

Wright, Andrew. 1976. Visual Materials for the Language Teacher. England Longman Group Ltd.

Willson, Julie. High and Low Achievers' Classroom Interaction Patterns in an Upper Primary Classroom. http://www.aare.edu.au/ggpap/Will99741.htm. [accessed $03 / 10 / 11 . \mathrm{G}$

Xiao-yan, Ma. 2006. Teacher Talk and EFL in University Classrooms. Asian EFL Journal (www.asian-efl-journal.com/thesis MaXiaou.pdf).

Yanfen Liu and Yuqin Zhao (2010). A Study of Teacher Talk in Interactions in English Classes. Chinese Journal of Applied Linguistics (Bimonthly), 33 (2), 1-11. 